\title{
Action Research on Improving Students' Speaking Proficiency in Using Cooperative Storytelling Strategy
}

\author{
- Dhani Ram Sharma
}

\begin{abstract}
Speaking is the first way to interact with others in the social community. Furthermore, the success in learning a language at first can be seen from the ability of the learner's speaking. However, it is very hard for the second language learners to speak the foreign language, especially English. There are a lot of reasons why they get difficulties in speaking, such as lack of ideas to tell, lack of vocabularies to express the ideas, lack of the exposure to speak, and lack of the interesting teaching method or technique that can motivate them to speak. Thus, this research applied Cooperative Storytelling Strategy to Improve Students' Speaking proficiency of the students of grade 11 in Nepal Rastriya Chandraganga Secondary School, Gagretal, Surkhet. This research was a collaborative classroom action research whose main purpose was to know whether or not storytelling strategy could improve the students'speaking skill. Meanwhile, the specific purposes consisted of describing: (1) To implement storytelling strategy in 11th graders students at our School to improve their speaking skill. (2)To enhance their confidence in speaking skill and create fluency in speaking. The data of this research were got from the observations done by Story telling contest and Speaking test. The result showed that there was an improvement on students' speaking proficiency after the implementation of storytelling strategy. The speaking test result in cycle two explained that the students'speaking aspects got good progress. Storytelling improved their comprehension, fluency, vocabulary, grammar, and pronunciation. Thus, it can be said that storytelling strategy could improve students'speaking skill.
\end{abstract}

Key words: Storytelling, Speaking Skill, Proficiency, Strategy, and Collaborative

\section{Background of the Study}

Language is a system for the expression of meaning. Its primary function is for interaction and communication. Language is used by human in order to know and understand each other. As 
we know that God created human in different condition and character, So they need to interact among people. People need a communication to know each other. It is a basic human activity, and basic of all human's communication is language. Language has some functions in people life, in everyday activities.

There are four skills in learning English they are listening, speaking, reading and writing. Speaking is very important because speaking and human being cannot be separated from each other. Speaking is used to express their ideas and to communicate to people in civilized world. Students' speaking problem can be solved by giving a lot chance to them for practicing English either in the classroom or out of classroom. Practicing speaking English in the classroom should be interested with appropriate technique in order to make students speaking skill can be improved and the process of learning can be enjoyable. One of technique can be used in teaching speaking is cooperative story telling. In order to build the bridge, in the speaking activities, the teacher must give them practice opportunity for purposeful communication in meaningful situation. It means learning to speak in a second language will be facilitated when learners are actively engaged in attempting to communicate.

One method used in order to improve communicative skills in a real context of the language is storytelling. Harmer (1998) proposed that teaching speaking must be focus on the real language use. For that reason, speaking as a productive skill on second language theories is considered as fundamental as the other skills when learning a language. According to Peck (1989) using the storytelling method learners are exposed to new vocabulary, real context, expressions and pronunciation to be used in oral production. Besides, storytelling method empowers and motivates learners to improve their speaking skill by presenting a tool that is not commonly used in Colombia in English classes. Speaking in English teaching is referred as an interactive process of constructing meaning that involves producing, receiving and processing information (Brown, 1994; Burns \& Joyce, 1997). Furthermore, Richards (1990) states that the mastery of speaking skill in English is seen as a priority for many EFL learners across the world because learners often evaluate their success in language learning based on how well they have improved in their spoken language skill. Consequently, different approaches have been implemented in order to increase the performance of the speaking skill in EFL learners, especially for young learners.

This action research study was designed to improve students' speaking proficiency by using cooperative story telling strategy. The storytelling guides teachers to tell personalized stories to the learners in their foreign language in this case, cooperative storytelling strategy has been implemented by language teachers all over the world especially in the field of teaching English as a foreign language. This powerful foreign language teaching method empowers teachers to improve Students' Speaking proficiency. 


\section{Importance/Rationale of the ARP}

Nepal Rastriya Chandraganga Secondary School is located in Surkhet district, it is government funded School and decided to use English as medium of instruction from grade 1 to 12 . This action research proposal was designed to improve students' speaking proficiency using cooperative storytelling strategy. The results of this research was expected to be useful for the English teacher of Nepal Rastriya Chandraganga Secondary School especially in teaching speaking teacher could manage classroom activities communicatively by using cooperative storytelling strategy . For students themselves, it could motivate them to try to speak English as often as possible, so that they could improve their ability in speaking skill.

\section{Speaking}

Speaking has acquired great importance along the history of English teaching since it is referred as an interactive process of constructing meaning that involves producing, receiving and processing information (Brown, 1994; Burns \& Joyce, 1997). English has become primordial worldwide for it has become a lingua franca. Therefore, it is the main source for communicating in many fields. Richards (1990) states that the mastery of speaking skill in English is seen as a priority for many EFL learners across the world. Moreover, he adds that learners consequently often evaluate their success in language learning as well as the effectiveness of their English course based on how well they feel they have improved in their spoken language skill. Brown (2007: 237)states that social contact in interactive language functions is a key in which it is not what you say that counts but how you say it, what you convey with body language, gestures, eye contact and other non- verbal message.

\section{Teaching Speaking}

A diversity of approaches has been implemented in order to increase the performance of the speaking skill in EFL learners. Given the fact that many languages do not have a written form, speaking is considered as the only source for communicating. An approach that has had areat impact on oral production is the Communicative language teaching (CLT). Unlike the audiolingual method, the CLT helps students to create meaningful phrases instead of repeating and memorizing grammar structures. The communicative function of the language is seen as the main objective rather than the perfect knowledge of the system. The CLT encourages the development of the speaking skill by promoting interaction as a mean for learning a language. It instigates learners to use the knowledge of the formal aspects of the language to communicate successfully in real-life situations.

\section{Cooperative Storytelling}

Storytelling, the art of narrating a tale from memory rather than reading is one of the oldest of all art forms. Storytelling is the original form of teaching and has the potential of fostering 
emotional intelligence and helps the child gain insight into human behavior. It also promotes language learning by enriching learners' vocabulary and acquiring new language structures. Moreover, storytelling can provide a motivating and low anxiety context for language learning. The storytelling tips given in this article are meant to help the teacher-as-storyteller as $\mathbf{s} /$ he prepares for a storytelling "performance" for students. Because language is an interactive process, children learning a language need ample opportunity to interact in a meaningful, interesting context and play with the language while developing vocabulary and structures. They need the collaboration of their peers and teachers in creating meaningful contexts and negotiating meanings in those contexts. The concept of learning is often considered to be different from acquisition. Acquisition is a natural process. A child would begin the process of first language acquisition at very early age. He would get enough exposure from his living environment by listening consciously or unconsciously to what people say around him. Learning process is different from acquisition. Students are placed in classroom settings, following teachers' instructions. The teacher should consider about many aspects that would affect the process of students' learning a second language for example, teaching environment, teaching method and materials, students' mentality, their ages and gender and so on. Mere subject knowledge is not enough to get employed. Good communication skill in general and in English language in particular has an upper hand to succeed in this competitive world. To improve the speaking ability of the students, there are many techniques that can be used such as practicing dialogues, playing games, singing songs, storytelling, oral reporting, role playing, small group discussions, giving speeches, news reading, poetry reading and debates. This study chose to use storytelling as a technique to try to improve the speaking abilities of students.

\section{Certain Characteristics of Storytelling}

- It provokes curiosity.

- It evokes student's imagination and interest in language skill.

- It builds vocabulary, comprehension, story sequencing.

- It improves listening and oral communication skills.

- It is an interactive and co-operative process.

- As an art it is an enjoyable tool for practicing language learning skills and verbal expressions.

- It binds listeners together.

- It helps the listener to remember.

- It uses all kinds of language conventions to make the story vivid.

- It makes listeners forget their misery.

\section{Objectives}

- To enable the students to learn English language skills

- To enhance their confidence and speaking skill 
- To increase the students knowledge of vocabulary, structure, context and grammar

- To develop problem solving skills

- To shed inhibition

- To teach narrative structure and practice description

- To create interest and develop listening comprehension

- To improve pronunciation and intonation

- To enhance the skills of connecting to content, connecting to learners and modeling

- To create fluency in speaking and to think about narration in writing

- To encourage interaction and share culture

\section{Problem Identification}

I have been teaching English in Nepal Rastriya Chandraganga Secondary school for 6 years. I noticed that most of the students in speaking class did not take part in speaking activities. They were nervous to produce utterances in English in or out of the classroom. Because of the speaking anxiety, they were unable to answer the questions in speaking test.

I thought there were various challenges that hinder students to deal with speaking skill. The students were not provided a lot of opportunity to speak in the class. They were not encouraged to speak English using variety of speaking strategies. I thought I could improve students' speaking proficiency by using cooperative story telling strategy in classroom. In this cycle of Action Research, I used 'cooperative story telling strategy' to improve speaking skill.

\section{Research Question}

How can I improve students' speaking proficiency in $11^{\text {th }}$ graders using Cooperative storytelling strategy in Nepal Rastriya Chandraganga Secondary School, Gagretal, Surkhet?

\section{Objectives of the Study}

The following objectives were designed to carry out this action research.

- To implement storytelling strategy in 11th graders students at our School to improve their speaking skill.

- To enhance their confidence in speaking skill and create fluency in speaking.

\section{Action Plan}

I completed the first cycle of the action research in the following way: 


\begin{tabular}{|c|c|c|c|c|}
\hline \multicolumn{5}{|c|}{ Action plan } \\
\hline Focus & \multicolumn{4}{|c|}{$\begin{array}{c}\text { Improving Students' Speaking proficiency in } 11^{\text {th }} \text { Graders Using } \\
\text { Cooperative Storytelling Strategy }\end{array}$} \\
\hline Why & \multicolumn{4}{|c|}{$\begin{array}{l}\text { - To implement storytelling strategy in } 11^{\text {th }} \text { graders students at our School to } \\
\text { improve their speaking skill. } \\
\text { - To enhance their confidence in speaking skill and create fluency in speaking. }\end{array}$} \\
\hline S.N. & What & How & Who & When \\
\hline 1. & $\begin{array}{l}\text { Preparation } \\
\text { of plan }\end{array}$ & $\begin{array}{l}\text { By writing } \\
\text { proposal }\end{array}$ & $\begin{array}{l}\text { Mr.Dhani Ram } \\
\text { Sharma }\end{array}$ & By August 10 \\
\hline 2. & $\begin{array}{l}\text { Implementation } \\
\text { of the action } \\
\text { plan }\end{array}$ & $\begin{array}{l}\text { Using Cooperative } \\
\text { storytelling strategy }\end{array}$ & $\begin{array}{l}\text { English language } \\
\text { teacher and } 11^{\text {th }} \text { graders } \\
\text { students }\end{array}$ & $\begin{array}{l}\text { August 14- } \\
\text { Sept } 21\end{array}$ \\
\hline 3. & $\begin{array}{l}\text { Data } \\
\text { collection }\end{array}$ & $\begin{array}{l}\text { - Diary notes } \\
\text { - Story telling contest } \\
\text { - Speaking test }\end{array}$ & $\begin{array}{l}\text { Mr.Dhani Ram } \\
\text { Sharma and students } \\
\text { of } 11^{\text {th }} \text { graders }\end{array}$ & Sept 22-Oct 10 \\
\hline 4. & $\begin{array}{l}\text { Report } \\
\text { writing }\end{array}$ & Typing report myself & $\begin{array}{l}\text { Mr. Dhani Ram } \\
\text { Sharma }\end{array}$ & Oct $11-$ Oct 25 \\
\hline
\end{tabular}

\section{Action/Intervention}

After, submitting the action plan, I started the action pre speaking test. First, I selected 25 students of grade 11 who were studying Linguistics as major. I prepared the questions for speaking test. Especially, I designed two types of questions for speaking test: General introduction and picture description. I decided to test following criteria through speaking test.
a. Comprehension
b. Vocabulary
c. Grammar
d. Pronunciation

I administered pre-test and analyzed the result of pre-test as follows: 


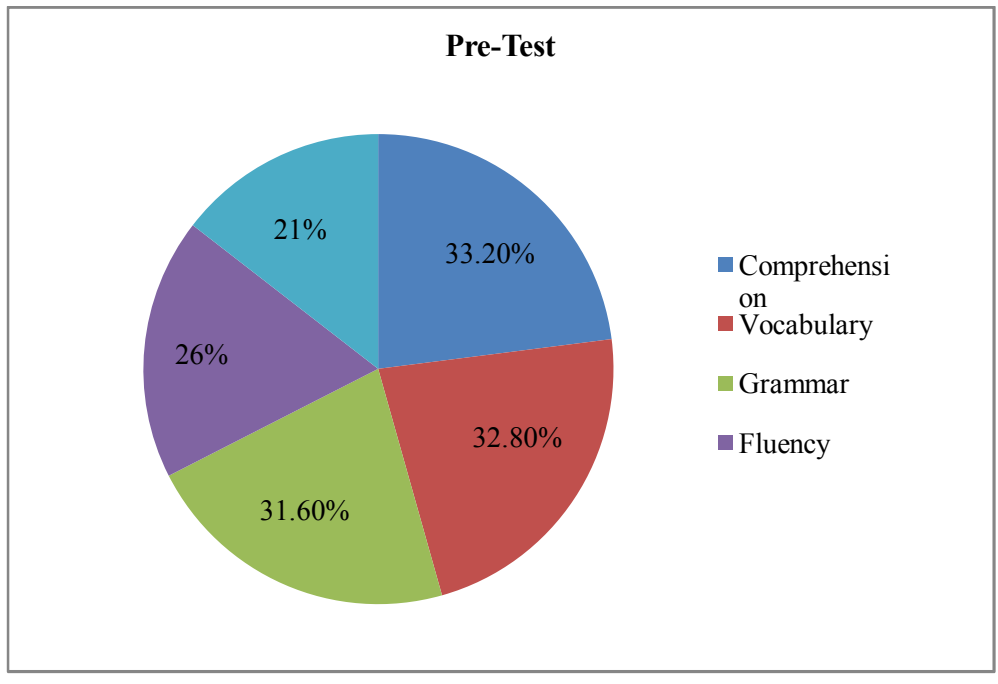

Figure 1

The result showed that the students scored $33.2 \%$ in comprehension, $32.8 \%$ in vocabulary, $31.6 \%$ in grammar, $26 \%$ in fluency and $21 \%$ in pronunciation aspect in speaking pre-test.

After that I implemented the Cooperative Storytelling technique to improve their speaking proficiency. First, I divided them into five groups in equal number. I presented them a video of a short story. After watching the video, I ask them to tell the same story in groups in chain. The students discussed in groups and told the story in chain. They told and retold the story in chain. I presented the video of new story every day for a week. Ten, I realized that they were motivated to speak with their friends. Then I changed the presentation of the story. Second, I broke down the story into five parts and provided a part of the story for each groups and asked them to read the given parts of the story in their own groups. After the completion of the reading parts of the story in each group, I asked all groups to combine every parts in correct order and create a story. After combining a whole story I asked them to tell the in chain in a circle. I changed the story everyday and I presented the written form of the parts of stories for a week.

\section{Observation}

After the implementation of the storytelling technique to develop their proficiency for two weeks, I conducted the story telling contest to observe their speaking proficiency. The students took part in the contest and they were able to tell stories that they had heard before. I also administrated post speaking test to measure their speaking skill. Finally, I analyzed the result and found that they improved their speaking proficiency. After using this technique, I found that my students were motivated to speaking English in and out of the classroom with their friends. The shy students also started to speak English in the classroom. I administered pre-test 
and analyzed the result of pre-test as follows:

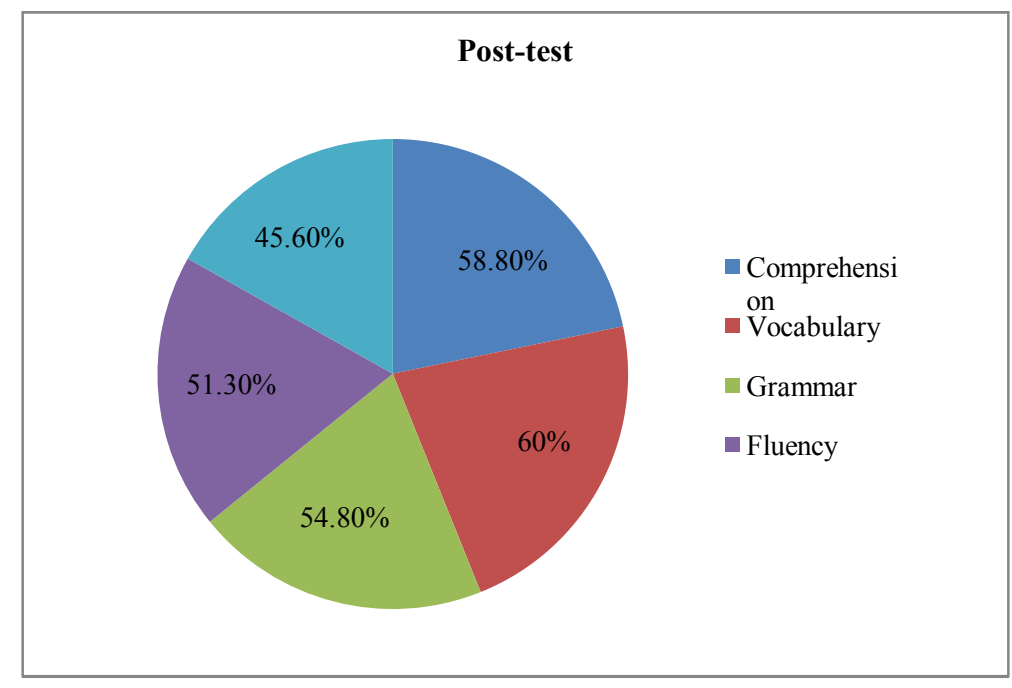

Figure 2

The result showed that the students scored $58.8 \%$ in comprehension, $60 \%$ in vocabulary, $54.8 \%$ in grammar, $51.30 \%$ in fluency and $45.60 \%$ in pronunciation. I found that the students' speaking proficiency was increased through the use of cooperative story telling technique.

\section{Conclusion}

After analyzing the result obtained in the post speaking test, I found that it helped for improvement, I will continued the techniques and I shared this idea with my fellow teachers and my colleagues in the school. I followed the action plan as in my action research proposal. My aim was to improve the students' speaking proficiency. As I conducted my research, I found the result as I assumed. The interventions I applied in my students really increased the participation in the speaking activities.

\section{Reference}

Brown, H. D. (1994). Principles of language learning and teaching. (3 ed), London: Longman Harmer, J. (1998). How to teach English: An introduction to the practice of English language teaching. Londan: Longman (2001). The practice of English language teaching. London: Longman

........ (1983). The practice of English language teaching. London: Longman
Nunan, D. (1991). Language teaching methodology: A textbook for teachers. Great Britain Rivers, W. M. (1981). Teaching foreign language skills. Chicago: London. 


\section{Appendixes}
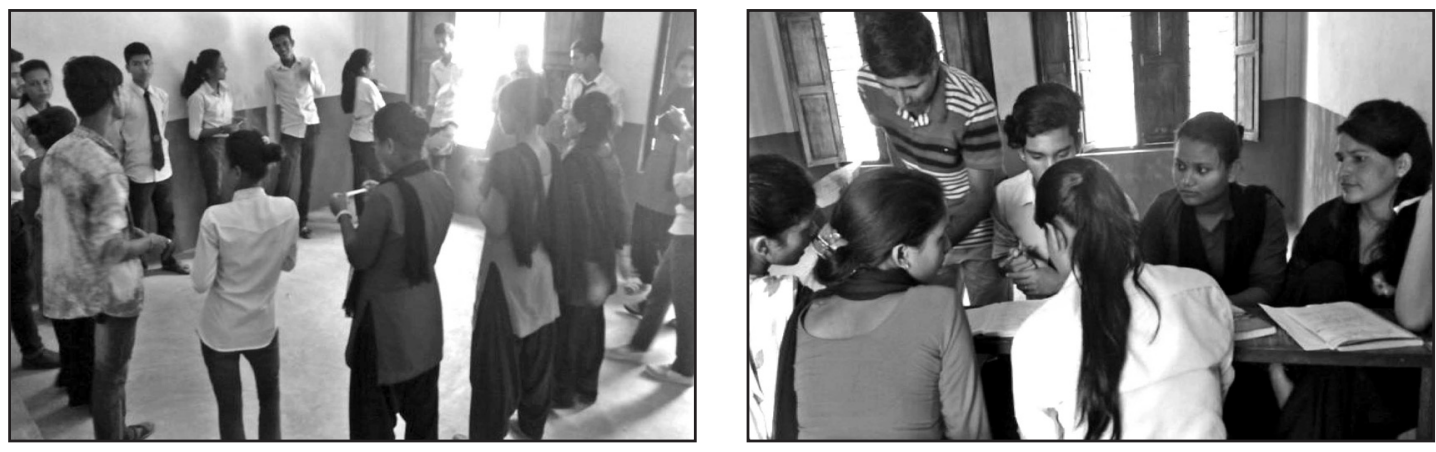

Students participating in cooperative storytelling activity

\section{Questions for Speaking Test - Part 1}

\section{General Introduction}

1. Tell me your name and address.

2. What do you like to do in your free time?

3. Why are you studying English?

4. What is your favorite subject in school?

5. What is your least favorite subject in school?

6. Can you briefly describe the plot of the last movie you saw?

7. Tell me about a time you took a long car trip.

8. How would your best friend describe you?

9. What is your favorite holiday?

10. Tell me about a special photograph in your home.

\section{Questions for Speaking Test - Part 2}

\section{Picture Description}
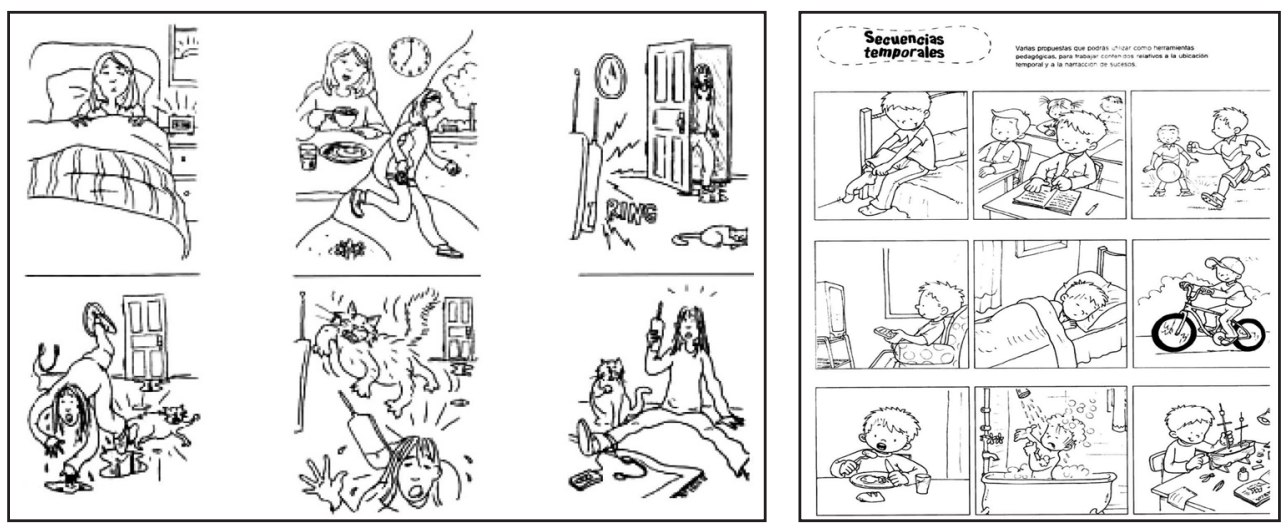